\title{
MANAJEMEN PEMBELAJARAN KELAS OLAHRAGA
}

\author{
Serly Masputri \\ Ahmad Yusuf Sobri \\ Desi Eri Kusumaningrum \\ Universitas Negeri Malang, Jl. Semarang 5 Malang 65145 \\ e-mail: serly.masputri@gmail.com
}

\begin{abstract}
The aims of the research are to describe: the lesson planning of sport classroom, sport classroom teaching organizised, exercise class learning implementation, evaluation of learning and resistance exercise class and gym class learning solutions. This study used a case study of qualitative approach. The data collection were by having interviews, observation and documentation. The results showed planners exercise class program involves the education, PENGCAB and KONI. Learning implementation is divided into academic and non-academic learning that involves each PENGCAB, and conducted evaluation to measure the success as well.
\end{abstract}

Keywords: Learning management and sport classroom.

\begin{abstract}
Abstrak: Penelitian ini bertujuan untuk mendeskripsikan: perencanaan pembelajaran kelas olahraga, pengorganisasian pembelajaran kelas olahraga, pelaksanaan pembelajaran kelas olahraga, evaluasi pembelajaran kelas olahraga dan hambatan serta solusi pembelajaran kelas olahraga. Penelitian ini menggunakan pendekatan kualitatif dengan jenis penelitian studi kasus. Pengumpulan data menggunakan wawancara, observasi dan dokumentasi. Hasil penelitian menunjukkan perencana program kelas olahraga melibatkan dinas pendidikan, PENGCAB dan KONI. Pelaksanaan pembelajaran terbagi menjadi pembelajaran akademik dan pembelajaran non akademik yang melibatkan PENGCAB olahraga masing-masing, serta dilakukan evaluasi untuk mengukur keberhasilan pembelajaran kelas olahraga.
\end{abstract}

Kata kunci: manajemen pembelajaran dan kelasolahraga.

Pendidikan merupakan proses pembelajaran yang diperoleh setiap mausia untuk dapat memahami suatu ilmu, lebih dewasa dalam membuat keputusan dan mampu lebih kritis dalam berpikir. Pendidikan itu sangat penting ditempuh oleh seluruh manusia untuk menjadi manusia yang lebih berkuakitas, baik dalam kehidupan sosial maupun dalam dunia pekerjaan, sehingga muncullah sekolah-sekolah yang unggul dari kualitas sekolahnya maupun dari programprogram sekolah. Berkembangnya zaman membuat sekolah-sekolah harus berlombalomba membuat program mandiri sekolah yang memberikan pengetahuan dan keterampilan baru bagi setiap peserta didik, suatu lembaga harus membuat inovasi baru atau ide gagasan baru untuk meningkatkan mutu sekolah sehingga peserta didik maupun masyarakat tertarik untuk menyekolahkan anak didiknya pada lembaga pendidikan tersebut.

Salah satu inovasi terbaru yang diselenggarakan oleh lembaga pendidikan adalah Pembelajaran Kelas Olahraga. Program ini dibuat untuk memberikan wadah bagi peserta didik yang memiliki prestasi dalam bidang olahraga dapat dibina lebih dengan penambahan jam khusus kelas olahraga namun tetap adanya proses pembelajaran pendidikan akademik, sehingga dengan adanya program pembelajaran kelas olahraga diharapkan peserta didik unggul dalam bidang akademik dan bidang non akademik. Hal tersebut sesuai dengan isi dari UndangUndang Republik Indonesia nomor 20 Tahun 2003 tentang Sistem Pendidikan Nasional Pasal 
5 Ayat 4 yang menyatakan "warga negara yang memiliki potensi kecerdasan dan bakat istimewa berhak memperoleh pendidikan khusus". Dunia olahraga di Indonesia saat ini dalam kondisi tidak sesuai harapan akibat kelemahan sumber daya manusia dan kesalahan sistem pembinaan. Kualitas SDM yang menangani bidang keolahragaan di Indonesia masih sangat terbatas, ini juga disebabkan oleh terbatasnya pelatihan untuk meningkatkan kualitas pelatih yang ada. Proses pelatihan di Indonesia sudah tertinggal jauh dari negara lain. Dunia olahraga harus terus berpacu dengan IPTEK, agar prestasi olahraga di Indonesia tidak merosot dan tidak tertinggal. Bisa dibilang Indonesia mengalami krisis bibitbibit atlet, karena kurangnya frekuensi kejuaraan usia dini dan sistem pembinaan yang tidak jelas. Oleh karena itu lembaga pendidikan harus menaungi peserta didik yang memiliki prestasi khusus terutama dalam bidang olahraga harus memberikan layanan pendidikan yang mewadahi agar proses belajar dalam kelas olahraga dapat berjalan lancar dalam bidang pembelajaran akademik maupun dalam bidang non-akademik. Dengan adanya kelas olahraga diharapkan dapat menumbuhkan bibit-bibit unggul sehingga bisa membawa nama sekolah ke jenjang nasional maupun internasional.

Penyelenggaraan kelas olahraga ini tertuang dalam Keputusan Direktur Pembinaan Sekolah Menengah Pertama Direktorat Jenderal Manajemen Pendidikan Dasar dan Menengah Kementerian Pendidikan Nasional Tahun 2010 tentang Penetapan Sekolah Penyelenggaraan Program Kelas Olahraga. Sesuai dengan isi surat keputusan tersebut menjelaskan, bahwa kelas olahraga dimaksudkan sebagai wadah untuk mengembangkan potensi dan bakat olahraga yang dimiliki oleh siswa. Satu-satunya Sekolah Menengah Atas yang ada di Batu yang menyelenggarakan kelas Olahraga adalah SMA Negeri 2 Batu, yang memberikan wadah tersendiri bagi lingkup lembaga pendidikan, mulai dari perencanaan pembelajaran, pengorganisaian pembelajaran, pelaksanaan pembelajaran, evaluasi pembelajaran serta masalah dan hambatan yang terjadi dalam pembelajaran kelas olahraga karena program ini berbeda dengan kelas reguler.

Menurut Madjid (2013:4) pembelajaran bermakna sebagai "upaya untuk membelajarkan seseorang atau kelompok orang melalui berbagai upaya (effort) dan berbagai strategi, metode dan pendekatan ke arah pencapaian tujuan yang telah direncanakan". Pembelajaran adalah suatu proses membuat seseorang belajar. Aktivitas pembelajaran harus memiliki rencana yang matang untuk menentukan bagaimana pembelajaran tersebut dapat mencapai tujuan secara efektif dan efesien. Rencana pembelajaran tersebut disiapkan dalam kegiatan pembelajaran, setelah rencana tersebut terealisasi, pendidik menyampaikan materi yang telah direncanakan dalam perencanaan pembelajaran. Terlebih dahulu Rohman dan Amri (2013:44) menjelaskan "perencanaan dapat diartikan sebagai proses penyusunan materi pelajaran, penggunaan media, pendekatan dan metode pembelajaran, dan penilaian dalam suatu alokasi waktu yang akan dilaksanakan pada masa tertentu untuk mencapai tujuan yang telah ditetapkan". Perencanaan pembelajaran yang matang berisi tentang tujuan yang akan dicapai, materi atau isi pembelajaran yang relevan dengan tujuan yang akan dicapai, interaksi belajar mengajar yang cocok dengan tujuan, media dan sumber belajar yang mendukung materi, bentuk dan teknik evaluasi yang tepat untuk mengukur pencapaian tujuan serta alokasi waktu yang diperlukan.

Menurut Sagala (2006:144) "pengorganisasian pembelajaran ini memberi gambaran bahwa kegitan belajar dan mengajar mempunyai arah dan penanggung jawab yang jelas ". Artinya dilihat dari komponen yang terkait dengan pembelajaran pada institusi sekolah memberi gambaran bahwa jelas kedudukan kepala sekolah dalam memberikan fasilitas dan kelengkapan pembelajaran, jelas kedudukan guru untuk mendesain pembelajaran dengan mengorganisasikan alokasi waktu, desain kurikulum, media dan kelengkapan pembelajaran. Sagala (2006:145) "pelaksanaan atau penggerakan dalam proses pembelajaran dilakukan oleh pendidik dengan suasana yang edukatif agar siswa dapat melaksanakan tugas belajar dengan penuh antusias, dan mengoptimalkan kemampuan belajarnya dengan baik". Berdasarkan pendapat tersebut maka pelaksanaan pembelajaran adalah proses kegiatan belajar mengajar sesuai dengan rencana untuk mencapai penguasaan kompetensi. Sedangkan 
komponen terakhir dalam fungsi perencanaan adalah evaluasi dimana menurut Madjid (2007:185) "penilaian merupakan pengukuran ketercapaian program pendidikan, perencanaan suatu program substansi pendidikan termasuk kurikulum dan pelaksanaannya, pengadaan dan peningkatan kemampuan guru, pengelolaan pendidikan, dan reformasi secara keseluruhan". Evaluasi dapat mengukur suatu keberhasilan dari perencanaan yang telah ditentukan.

Menurut Paturusi (2012:5) "pendidikan jasmani dan olahraga (penjasor) adalah proses pendidikan melalui aktivitas jasmani dan olahraga yang terpilih untuk mencapai tujuan pendidikan. Dengan demikian pendidikan jasmani dan olahraga dapat diartikan suatu kegiatan mendidik anak atau seseorang dengan proses pendidikan melalui aktivitas jasmani dan olahraga. Kelas olahraga dimaksudkan sebagai wadah untuk mengembangkan potensi dan bakat olahraga yang dimiliki oleh peserta didik. Penyelenggaraan kelas olahraga akan berhasil bila terdapat manajemen yang baik. Manajemen pembelajaran kelas olahraga merupakan kunci keberhasilan dari pembelajaran di kelas olahraga. Manajemen pembelajaran dapat diartikan sebagai seni dan ilmu mengelola sumber daya pendidikan mencapai tujuan pendidikan secara efektif dan efesien sehingga memperoleh hasil yang maksimal sesuai dengan tujuan pembelajaran.

Permasalahan pada pembelajaran kelas olahragatidaksemata-mataberawaldarirendahnya kualitas pembelajaran yang dilaksanakan oleh guru, tetapi lebih dari itu terdapat berbagai kendala lain, yang merupakan determinan rendahnya apresisiasi siswa terhadap pendidikan jasmani dan olahraga. Menurut Mu'arifin (2009:96) permasalahan yang muncul pada pembelajaran pendidikan jasmani dan olahraga yaitu masih didominasi oleh guru; waktu aktif belajar/bergerak (academic learning time) sangat sedikit, karena terlalu banyak waktu yang habis untuk menunggu giliran; kegiatan pembelajaran berorientasi pada pelatihan olahraga; cenderung ditekankan pada penguasaan keterampilan gerak, bukan belajar melalui gerak atau mendidik siswa melalui gerak; masalah-masalah itu diperparah oleh sarana dan prasarana yang kurang memadai, yaitu kurang lengkapnya alat-alat dan minimnya lapangan. Permasalahan-permasalahan tersebut tentunya mempunyai alternatif pemecahan masalah untuk mengatasi masalah yang terjadi di pembelajaran kelas olahraga dan meminimalisai masalah baru yang akan muncul, dengan demikian sebaiknya pembelajaran kelas olahraga atau pembelajaran pendidikan jasmani dan olahraga hendaknya mengacu pada prinsip-prinsip berikut:1) disesuaikan dengan karakteristik siswa; 2) menggunakan pendekatan bermain yang mengarah pada prinsip fun \& busy; 3) mengarahkan pada pengembangan multirateral; 4) memberi pengalaman pada siswa dalam melakukan problem solving-discovery; 5) memberi peluang pada siswa untuk memperoleh kebebasan gerak, melakukan eksplorasi/penjelajahan gerak yang beragam; 6) merangsang dan melatih siswa agar berani mengambil inisiatif-kreatifitas-imajinasi (decision maker); dan 7) pembelajaran diarahkan pada pocess oriented dan success structured: (pembelajaran yang menekankan pada proses dan dirancang secara sistematis sehingga bisa merasakan dan mengalami keberhasilan).(Mu'arifin, 2009:97).

\section{METODE}

Penelitian ini menggunakan pendekatan kualitatif, karena peneliti ingin mengungkapkan tentang Manajemen Pembelajaran Kelas Olahraga di SMA Negeri 2 Batu secara mendalam. Peneliti menggunakan pendekatan kualitatif dimaksudkan untuk membuktikan kajian yang mendalam mengenai kejadian istimewa dan dapat memaparkan secara lugas mengenai manajemen pembelajaran kelas olahraga di SMA Negeri 2 Batu deskripsi dipaparkan secara lebih mendalam mengenai masalah-masalah yang terjadi pada fokus penelitian pendekatan kualitatif karena masalah yang diteliti adalah fenomena sosial yang tidak dapat diungkap melalui prosedur pengukuran atau statistik. Jenis penelitian ini menggunakan jenis penelitian dengan studi kasus. Peneliti memilih menggunakan metode studi kasus karena penelitian terfokus pada satu latar yaitu SMA Negeri 2 Batu. Menurut Ulfatin (2013:48) studi kasus adalah "suatu metode penyelidikan secara langsung dengan latar yang alamiah dan memusatkan perhatian pada suatu peristiwa secara intensif dan rinci". Penelitian ini menggunakan jenis penelitian studi kasus, karena peneliti ingin menemukan menganalisis masalah yang ada lebih 
mendalam, menyeluruh dan utuh. Studi kasus lebih menekankan pengungkapan fakta yang terdapat di lapangan secara rinci dan mendalam dalam suatu objek atau peristiwa dari lapangan.

Lokasi penelitian merupakan pusat informasi dalam sebuah penelitian, lokasi penelitian ini yaitu di SMA Negeri 2 Batu yang berlokasi di Jalan Bhayangkara 14 Junrejo Kota Batu telp (0341) 465454. SMA Negeri 2 Batu merupakan sekolah satu-satunya jejang Menengah Atas yang mempunyai kelas olahraga. Sekolah yang sudah memiliki banyak prestasi dalam bidang akademik dan non akademik. SMA Negeri 2 Batu mempunyai ciri khas sendiri karena mempunyai kelas olahraga hal ini menjadi daya tarik sekolah dalam menjaring peserta didik baru untuk bergabung dengan sekolah.

Sumber data dalam penelitian, adalah subjek di mana data diperoleh. Menurut Lofland (dalam Moleong, 2012:157) bahwa "sumber data utama dalam penelitian kualitatif ialah kata-kata atau tindakan, selebihnya adalah adalah data tambahan seperti dokumen dan lain-lain". Sumber data terdiri dari dua macam yaitu data tidak tertulis dan data tertulis. Data tidak tertulis adalah data-data yang berupa kata-kata tindakan yang diperoleh dari orang yang diamati atau diwawancarai selama penelitian berlangsung, dalam penelitian ini kata-kata atau tindakan berupa jawaban dari informan dan hasil catatan lapangan dari berbagai informan, di antaranya adalah kepala sekolah, waka kurikulum, koordintaor kelas olahraga, guru kelas olahraga, KONI Kota Batu, PENGCAB Kota Batu, maupun peserta didik kelas olahraga terkait dengan bagaimana Manajemen pembelajaran kelas olahraga di SMA Negeri 2 Batu. Sedangkan data tertulis adalah data tertulis adalah data-data yang diperoleh melalui berbagai sumber tertulis seperti buku-buku, arsip, hasil evaluasi peserta didik, maupun dokumen resmi dari SMA Negeri 2 Batu.Pengumpulan data dalam penelitian ini dilakukan melalui: (1) wawancara; (2) observasi; dan (3) studi dokumentasi. Pengecekan keabsahan data dalam penelitian ini digunakan tes: credibility (derajat kepercayaan), dan confirmability (kepastian). Tahap-tahap yang ditempuh dalam penelitian ini yaitu tahan perencanaan atau pra lapangan, penyusunan proposal, tahap pelaksanaan, tahap analisis data dan tahap penulisan laporan.

\section{HASIL}

\section{Perencanaan Pembelajaran Kelas Olahraga di SMA Negeri 2 Batu}

Perencanaan pembelajaran kelas olahraga di SMA Negeri 2 Batu terdiri menjadi empat jenis perencanaan yaitu perencanaan jenis program, perencanaan bidang pembelajaran, penyusunan perencanaan pihak yang terlibat dan perencanaan pekan efektif. Pertama perencanaan jenis program terdiri dari beberapa yaitu perencanan kelas olahraga terlebih dahulu melakukan identifikasi jenis dan macam olahraga yang akan ditampung oleh sekolah, melakukan seleksi apakah peserta didik memiliki prestasi olahraga atau dengan cara menunjukkan bukti piagam juara bahwa mereka berprestasi dalam bidang olahraga melakukan kerjasama dengan KONI dalam hal pembinaan keatletan bersama cabang-cabang olahraga atau dengan pengurus cabang olahraga masing-masing. Kedua pada perencanaan bidang pembelajaran yaitu kelas olahraga di SMA Negeri 2 Batu ini menerapkan kurikulum 2013 sama dengan kelas reguler yaitu menggunakan Kurikulum K13 namun ada modifikasi kurikulum dimana kebijakan pengurangan 10 jam pelajaran, pengurangan 10 jam pelajaran untuk pembelajaran non akademik yang dapat digunakan untuk latihan peserta didik kelas olahraga, dankelas olahraga mempunyai program tahunan yaitu dengan adanya perencanaan pengadaan pembelajaran dengan menggunakan modul untuk mengompen jam pelajaran yang ditinggalkan selama 2 jam pelajaran. Ketiga penyusunan pihak yang terlibat yaitu enyusunan perencanaan pembelajaran kelas olahraga di SMA Negeri 2 Batu disusun secara bersama-sama dengan melibatkan kepala sekolah, wakil kepala sekolah, guru olahraga, guru BK, komite sekolah, dan yang jelas ada rekomendasi dari dinas maupun dari KONI dan ada sosialisasi untuk orang tua yang ada di kelas olahraga itu satu bulan setelah pelaksanaan PPDB. Keempat perencanaan pekan efektif yaitukelas olahraga pekan efektif jam pelajarannya dalam satu minggu ada pengurangan jam yaitu 10 jam pelajaran untuk latihan sesuai dengan jadwal masing-masing cabang olahraga dan rincian pembelajaran kelas olahraga pada jam ke 1-6 pembelajaran akademik dengan pedoman RPP 
dengan tatap muka sedangakan pada jam ke 7-8 dengan non akademik dengan pedoman program latihan dan dilaksanakan sesuai masing-masing tempat cabang olahraganya.

\section{Pengorganisasian Pembelajaran Kelas Olahraga di SMA Negeri 2 Batu}

Adanya alur koordinasi atau kerjasama dalam pengadaan pembelajaran kelas olahraga dari Dinas Pendidikan Kota Batu yang kemudian melimpahkan kepada Komite Olahraga Nasional (KONI) Kota Batu alur selanjutnya berkoordinasi dengan SMA Negeri 2 Batu tentang pembelajaran kelas olahraga, tahap berikutnya SMA Negeri 2 Batu meminta bantuan sarana prasarana maupun pelatih yang membantu dalam pembelajaran olahraga, kemudian KONI melakukan koordinasi dengan Pengurus Cabang Olahraga masingmasing cabang olahraga yang ada di Kota Batu untuk membina atlet-atlet atau peserta didik yang ada di kelas olahraga SMA Negeri 2 Batu. pengelolaan kelas olahraga dalam lingkup sekolah yang berupa struktur pengelolaan kelas olahraga di SMA Negeri 2 Batu, dalam struktur kelas olahraga tersebut terlihat jelas pembagian tugas masing-masing serta tanggung jawab yang sesuai kedudukan dan wewenang. Penerimaan peserta didik kelas olahraga di SMA Negeri 2 Batu tidak sembarangan dalam menerima peserta didik kelas olahraga, peserta didik yang masuk harus mempunyai rekomendasi dari Komite Olahraga Nasional Indonesia (KONI) Kota Batu dengan persyaratan peserta didik itu harus mempunyai bakat, minat, prestasi dalam cabang olahraga yang mereka pilih. Pengorganisasian peserta didik kelas olahraga ini semua peserta didik kelas olahraga masuk ke dalam jurusan IPS karena kemampuan peserta didik kelas olahraga yang berbeda dengan kelas reguler, karakter peserta didik kelas olahraga berbeda dengan kelas reguler yang lebih aktif dan lebih menonjolkan motoriknya namun guru mempunyai cara membuat peserta didik nyaman dengan mengerti karakter peserta didik, membiarkan peserta didik untuk berpendapat dan bertingkah sesuai keinginan mereka namun tetap harus sesuai dengan norma dan peraturan yang belaku.

\section{Pelaksanaan Pembelajaran Kelas Olahraga di SMA Negeri 2 Batu}

Sistem pembelajaran pada kelas olahraga terbagi menjadi 2 sistem yaitu pertama sistem pembelajaran akademik pada jam pelajaran ke 1 sampai ke 6 yaitu jam 07.00 sampai 11.45 sedangkan pembelajaran non akademik dilaksanakan pada jam pelajaran 7 sampai jam ke 8 yaitu pukul 12.15 sampai 13.45. Menutupi 2 jam pelajaran non akademik peserta didik harus memenuhi tuntutan kurikulum yang ada di SMA Negeri 2 Batu dengan mengerjakan semacam pekerjaan rumah SMA Negeri 2 Batu menyebutkannya dengan modul pengganti pembelajaran non akademik. Modul tersebut dapat dikerjakan peserta didik dirumah sebagai pengganti 2 jam pelajaran yang mereka tinggalkan. Strategi peserta didik kelas olahraga yaitu peserta didik dapat dispensasi khusus untuk mengikuti perlombaan maupun latihan sehingga bebas berlatih dengan maksimal namun jika ada ulangan atau ada tugas maka peserta didik harus menyusul ulangan dan tetap mengerjakan tugas yang ditinggalkan dan strategi yang terakhir ada penambahan jadwal latihan agar saat mengikuti kompetisi hasilnya maksimal.

\section{Evaluasi Pembelajaran Kelas Olahraga di SMA Negeri 2 Batu}

Aspek yang dinilai dalam pembelajaran kelas olahraga merujuk pada kurikulum 2013 pada tiga penilaian yang digunakan yaitu penilaian afektif (sikap), kognitif (pengetahuan), dan psikomotorik (keterampilan). Penilaian sikap dengan menggunakan metode observasi dan pengamatan $\mathrm{h}$ menilai kompetensi sikap yang terbagi menjadi sikap spiritual dan sikap sosial SMA Negeri 2 Batu hanya menggunakan bentuk penilaian sikap dengan penilaian observasi atau pengamatan dan penilaian dengan jurnal. Kompetensi penilaian keterampilan terdiri atas keterampilan abstrak dan keterampilan kongkret. Penilaian keterampilan kelas olahraga di SMA Negeri 2 Batu menggunakan penilaian praktik, peserta didik dilakukan dengan cara mengamati kegiatan peserta didik dalam melakukan sesuai dengan yang dilaksanakan dengan menggunakan skala penilaian. Kelas olahraga menetapkan 
target pencapaian yang menjadi patokan nilai, yaitu dengan memperhatikan Kriteria Ketuntasan Minimal (KKM) yang harus memenuhi standar nilai mencapai 75 pada setiap mata pelajaran. Jika mereka salah satu pelajarannya tidak lulus dalam UTS maupun UAS mereka bisa mengikuti remidi yang diadakan oleh guru masingmasing dengan mengambil formulir atau kartu remidi. Bentuk penilaian yang digunakan untuk mengukur keberhasilan belajar peserta didik dengan menggunakan tes tulis yang meliputi tugas harian, Ulangan Harian (UH), Ujian Tengah Semester (UTS), Ujian Akhir Semester (UAS), dan Ujian Nasional (UN). Pihak yang terlibat dalam pemberian nilai adalah guru mata pelajaran masing-masing yang memberikan nilai akhir sedangkan pada nilai olahraga atau nilai keatletannya akan di isi diraport tentang nilai keahliannya yang diberi nilai oleh pengurus cabang olahraga masing-masing. Laporan Hasil Belajar peserta didik kelas olahraga sama dengan kelas reguler yaitu berupa raport hasil belajar peserta didik.

\section{Hambatan dan Solusi Dalam Pembelajaran Kelas Olahraga di SMA Negeri 2 Batu}

\section{Hambatan dalam Pembelajaran Kelas Olahraga}

Hambatan dalam proses pembelajaran kelas olahraga adalah jam pembelajaran akademik peserta didik kelas olahraga yang dikurangi baik untuk jam latihan maupun jam dispensasi khusus saat mereka mengikuti kompetisi sehingga pada kelas XII saat mereka akan mengikuti Ujian Nasional mereka sangat kesulitan dalam mengerjakan soal Ujian Nasional. Faktor penghambat kedua juga terjadi pada tenaga pendidik yang kurang menyadari karakter peserta didik kelas olahraga, guru tersebut ketika mengajar di kelas olahraga memperlakukan sama dengan kelas reguler kadang ada guru yang kurang menyadari hal tersebut sehingga nilai dari anak kelas olahraga menjadi kurang. Hambatan ketiga adalah masalah biaya dikarenakan pada SMA Negeri 2 Batu ini sudah tidak ada uang SPP maupun uang bantuan yang lainnya sehingga menimbulkan kendala dalam pelaksanaan kelas olahraga yang harus mempunyai biaya besar. Masalah sarana dan prasarana olahraga yang kurang memadai di SMA Negeri 2 Batu karena keterbatasan biaya

\section{Solusi dalam Pembelajaran Kelas Olahraga}

Solusi dalam hambatan-hambatan tersebut adalah memodifikasi kurikulum pembelajaran dengan pengurangan 10 jam pelajaran diganti dengan pembelajaran menggunakan modul sehingga peserta didik kelas olahraga tidak tertinggal pelajaran dari kelas reguler. Pengadaan semacam remidi untuk peserta didik kelas olahraga yang nilainya dibawah Kriteria Ketuntasan Minimal (KKM) yaitu 75. solusi kesadaran guru sekolah memberikan semacam pemahaman bahwa karakter peserta didik itu berbeda-beda begitu pula karakter peserta didik kelas olahraga dengan karakter peserta didik kelas reguler. Bantuan dari dana Dinas Pendidikan Kota Batu maupun dari PENGCAB atau Pengurus Cabang maupun Wali kota Batu jadi sekolah mengajukan dana dari dinas pendidikan kemudian dinas pendidikan membantu sekolah. Solusi terakhir Meminta bantuan kepada Wali Kota Batu untuk pembebasan biaya sewa latihan di Stadion Brantas dan meminta bantuan kepada masing-masing Pengurus Cabang Olahraga untuk ketersediaan alat-alat berlatih

\section{PEMBAHASAN}

\section{Perencanaan Pembelajaran Kelas Olahraga di SMA Negeri 2 Batu}

Perencanaan pembelajaran tersebut diadakan setiap menjelang awal tahun ajaran baru. Kegiatan pembelajaran selama satu tahun ajaran disesuaikan dengan kalender pendidikan, yang didalamnya termuat antara lain permulaan awal tahun pelajaran, minggu efektif belajar, waktu pembelajaran efektif, dan hari libur nasional. Perencanaan pembelajaran Rohman dan Amri (2013:44) menjelaskan "perencanaan dapat diartikan sebagai proses penyusunan materi pelajaran, penggunaan media, pendekatan dan metode pembelajaran, dan penilaian dalam suatu alokasi waktu yang akan dilaksanakan pada masa tertentu untuk mencapai tujuan yang telah ditetapkan". Semua proses perencanaan pembelajaran digunakan sebagai perangkat dalam melaksanakan pembelajaran kelas olahraga di SMA Negeri 2 Batu. Perencanaan pembelajaran kelas olahraga di SMA Negeri 2 Batu telah melalui berbagai persiapan yang matang sebelum program pembelajaran dilaksanakan. Sebab 
kegiatan pembelajaran akan berjalan dengan baik jika konsep serta tahapan dalam pembelajaran yang terdiri dari perencanaan, pengorganisasian, pelaksanaan serta evaluasi dapat disusun dengan baik. Kelas olahraga SMANegeri 2 Batu berupaya memenuhi konsep tersebut dimana rancangan pembelajaran selalu dilaksanakan setiap awal tahun ajaran baru dengan melibatkan beberapa warga sekolah, dan ada sosialisas melibatkan orang tua dari peserta didik kelas olahraga.

\section{Pengorganisasian Pembelajaran Kelas Olahraga di SMA Negeri 2 Batu}

Bentuk pengorganisasian pembelajaran kelas olahraga di SMA Negeri 2 Batu menggambarkan tentang kedudukan atau wewenang secara hirarki dari suatu unit kerja ditempati seperti Dinas Pendidikan, Komite Olahraga Nasional Indonesia (KONI) Batu, SMA Negeri 2 Batu, dan Pengurus Cabang Olahraga. Lebih khusus lagi alur koordinasi atau kerjasama dalam pengadaan pembelajaran kelas olahraga dari Dinas Pendidikan Kota Batu yang kemudian melimpahkan kepada Komite Olahraga Nasional (KONI) Kota Batu alur selanjutnya berkoordinasi dengan SMA Negeri 2 Batu tentang pembelajaran kelas olahraga, tahap berikutnya SMA Negeri 2 Batu meminta bantuan sarana prasarana maupun pelatih yang membantu dalam pembelajaran olahraga, dan terakhir KONI melakukan koordinasi dengan Pengurus Cabang Olahraga masing-masing cabang olahraga yang ada di Kota Batu untuk membina atlet-atlet atau peserta didik yang ada di kelas olahraga SMA Negeri 2 Batu. Hal ini sesuai dengan pernyataan Sagala (2006:144) "pengorganisasian pembelajaran ini memberi gambaran bahwa kegitan belajar dan mengajar mempunyai arah dan penanggung jawab yang jelas".

\section{Pelaksanaan Pembelajaran Kelas Olahraga di SMA Negeri 2 Batu}

Pelaksanaan pembelajaran non akademik kelas olahraga juga berlangsung seusai dengan jadwal latihan masing-masing cabang olahraga. Peserta didik kelas olahraga harus bisa membagi waktu dengan baik antara jadwal pembelajaran dengan jadwal latihan, apalagi jika peserta didik kelas olahraga mengikuti kompetisi atau mengikuti turnamen maupun lomba sehingga harus ada strategi sekolah jika atletnya ikut ke dalam suatu perlombaan misalnya dengan adanya ulangan susulan jika ada ulangan pada jam yang ditinggalkan, ada dispensai khusus, maupun ada jam tambahan latihan. Sehingga guru harus mengerti dalam proses pelaksanaan tersebut guru harus memberikan ulangan susulan pada jam yang berbeda memberikan dispensai kepada peserta didik yang mengadakan turnamen atau perlombaan, maupun memberikan permudahan dengan penambahan jadwal latihan. Hal tersebut diberikan agar peserta didik dapat melaksanakan tugas dengan semaksimal mungkin baik tugas akademik maupun tugas non akademik. Hal tersebut sesuai dengan pendapat dari Sagala (2006:145) "pelaksanaan atau penggerakan dalam proses pembelajaran dilakukan oleh pendidik dengan suasana yang edukatif agar siswa dapat melaksanakan tugas belajar dengan penuh antusias, dan mengoptimalkan kemampuan belajarnya dengan baik".

\section{Evaluasi Pembelajaran Kelas Olahraga di SMA Negeri 2 Batu}

Bentuk penilaian kelas olahraga terdiri dari tugas modul, ulangan harian, ujian tengah semester, ujian akhir semester, ujian praktik untuk kelas XII dan ujian nasional. Pemberian nilai akademik dalam kelas olahraga dilimpahkan pada masing-masing guru mata pelajaran, sedangkan nilai olahraga atau nilai non akademiknya dipercayakan kepada pelatih masing-masing cabang olahraga yang kemudian diberikan kepada guru olahraga di SMA Negeri 2 Batu. Ulangan Harian (UH) dilaksanakan oleh masing-masing guru mata pelajaran jika pokok bahasan atau materi telah selesai, Ujian Tengah Semester (UTS) dan Ujian Akhir Semester (UAS) dilaksanakan tiap semesternya setelah beberapa kalipertemuan sesuaidengan kalenderpendidikan, sedangkan ujian nasional dilaksanakan satu kali pada bulan April sesuai dengan keputusan menteri pendidikan. Sedangkan bentuk laporan hasil belajar peserta didik berupa raport yang diberikan tiap tengah semester dan raport akhir semester. Isi raport berupa nilai peserta didik berdasarkan nilai dari modul, Ulangan Harian (UH), Ujian Tengah Semester (UTS) maupun Ujian Akhir Semester (UAS) dengan bentuk 
skala penilaian 10-100. Mengetahui berhasil atau tidaknya peserta didik tersebut maka diperlukan adanya evaluasi. Penilaian ini bertujuan untuk mengukur keberhasilan pembelajaran di kelas olahraga dan mengukur kemampuan peserta didik sendiri. Hal ini didukung oleh Madjid (2007:185) "penilaian merupakan pengukuran ketercapaian program pendidikan, perencanaan suatu program substansi pendidikan termasuk kurikulum dan pelaksanaannya, pengadaan dan peningkatan kemampuan guru, pengelolaan pendidikan, dan reformasi secara keseluruhan".

\section{Hambatan dan Solusi Dalam Pembelajaran Kelas Olahraga di SMA Negeri 2 Batu}

\section{Hambatan dalam Pembelajaran Kelas Olahraga}

Setiap sistem pembelajaran pasti terdapat hambatan dalam proses pelaksanaanya, tidak terkecuali dalam pembelajaran kelas olahraga, hambatan yang sering muncul yaitu, jam pembelajaran akademik peserta didik kelas olahraga yang dikurangi tenaga pendidik yang kurang menyadari karakter peserta didik kelas olahraga, kurangnya kesadaran guru tersebut membuat nilai peserta didik menjadi kurang, masalah biaya atau dana dikarenakan pada SMA Negeri 2 Batu ini sudah tidak ada uang SPP maupun uang bantuan yang lainnya serta kurangnya sarana prasarana di kelas olahraga seperti tidak adanya lapangan latihan sehingga harus menyewa lapangan.Temuan peneliti sejalan dengan pendapat Mu'arifin (2009:96) permasalahan yang muncul pada pembelajaran pendidikan jasmani dan olahraga yaitu masih didominasi oleh guru; waktu aktif belajar/ bergerak (academic learning time) sangat sedikit, karena terlalu banyak waktu yang habis untuk menunggu giliran; kegiatan pembelajaran berorientasi pada pelatihan olahraga; cenderung ditekankan pada penguasaan keterampilan gerak, bukan belajar melalui gerak atau mendidik siswa melalui gerak; masalah-masalah itu diperparah oleh sarana dan prasarana yang kurang memadai, yaitu kurang lengkapnya alat-alat dan minimnya lapangan. Berdasarkan pemaparan tersebut dapat disimpulkan bahwa, perlu adanya kesadaran antara guru kelas olahraga untuk memahami karakter peserta didik kelas olahraga, dan adanya dana yang cukup untuk mengelola kelas olahraga agar program pembelajaran yang sudah dibuat dapat berjalan dengan sebaik mungkin.

\section{Solusi dalam Pembelajaran Kelas Olahraga}

Semua sistem pendidikan memiliki kelebihan dan kekurangan, tanpa terkecuali dalam pembelajaran kelas olahraga, untuk mengatasi hambatan tersebut ada beberapa alternatif pemecahan yang bisa digunakan antara lain, memodifikasi kurikulum pembelajaran dengan pengurangan 10 jam pelajaran diganti dengan pembelajaran menggunakan modul, pengadaan semacam remidi untuk peserta didik kelas olahraga yang nialinya dibawah Kriteria Ketuntasan Minimal (KKM) yaitu 75, untuk solusi kesadaran guru sekolah memberikan semacam pemahaman bahwa karakter peserta didik itu berbeda-beda yaitu dengan menyesuaikan masing-masing karakter peserta didik, bantuan dari dana dinas pendidikan maupun dari PENGCAB atau Pengurus Cabang terkait dengan sarana prasana maupun dana.

Solusi untuk mengatasi hambatan yang ada dalam pembelajaran kelas olahraga senada dengan pendapat Mu'arifin (2009:97) mengenai dengan hambatan kurangnya kesadaran guru terhadap peserta didik kelas olahraga yaitu sebagai berikut: (a) disesuaikan dengan karakteristik siswa; (b) menggunakan pendekatan bermain yang mengarah pada prinsip fun \& busy; (c) mengarahkan pada pengembangan multirateral; (d) memberi pengalaman pada siswa dalam melakukan problem solving-discovery; (e) memberi peluang pada siswa untuk memperoleh kebebasan gerak, melakukan eksplorasi/ penjelajahan gerak yang beragam; (f) merangsang dan melatih siswa agar berani mengambil inisiatif-kreatifitas-imajinasi (decision maker); dan (f) pembelajaran diarahkan pada pocess oriented dan success structured: (pembelajaran yang menekankan pada proses dan dirancang secara sistematis sehingga bisa merasakan dan mengalami keberhasilan). Berdasarkan uraian tersebut dapat diambil kesimpulan bahwa, peserta didik mempunyai karakter berbedabeda dan tidak bisa disamakan antara peserta didik kelas reguler dengan peserta didik kelas olahraga sehingga guru harus memahami konsep bahwa karakter peserta didik itu berbeda-beda dan memberi peluang pada peserta didik untuk memperoleh kebebasan dalam belajar akademik maupun non akademik. 


\section{SIMPULAN DAN SARAN}

\section{Simpulan}

Berdasarkanhasil penelitiandan pembahasan, dapat dikemukakan beberapa kesimpulan tentang manajemen pembelajaran kelas olahraga yaitu perencanaan pembelajaran kelas olahraga terbagi menjadi empat perencanaan yaitu perencanaan jenis program, perencanaan bidang pembelajaran, penyusunan pihak yang terlibat dan perencanaan pekan efektif.

Kedua Adanya alur kordinasi atau kerjasama dalam pengadaan pembelajaran kelas olahraga dengan Dinas Pendidikan, PENGCAB dan KONI, membuat struktur pengelolaan kelas olahraga di SMA Negeri 2 Batu, Peserta didik yang masuk harus mempunyai rekomendasi dari (KONI) Kota Batu dengan persyaratan peserta didik itu harus mempunyai bakat dan minat dalam cabang olahraga, peserta didik kelas olahraga masuk ke dalam jurusan IPS, karakter peserta didik kelas olahraga lebih aktif dan lebih menonjolkan motoriknya.

Ketiga sistem pembelajaran pada kelas olahraga terbagi menjadi 2 sistem yaitu pembelajaran akademik pada jam pelajaran ke 1 sampai ke 6 sedangkan pembelajaran non akademik pada jam pelajaran 7 sampai jam ke 8 , menutupi 2 jam pelajaran non tatap muka peserta didik harus mengerjakan modul pembelajaran pengganti 2 jam pelajaran yang ditinggalkan, strategi peserta didik kelas olahraga yaitu peserta didik dapat dispensasi khusus untuk mengikuti perlombaan maupun latihan sehingga bebas berlatih.

Keempat ada Tiga aspek penilaian yang digunakan yaitu penilaian afektif (sikap), kognitif (pengetahuan), dan psikomotorik (keterampilan). kriteria Ketuntasan Minimal (KKM) mencapai 75 pada setiap mata pelajaran, pengadaan remidi dengan mengambil formulir atau kartu remidi jika nilai kurang dari KKM, Pihak yang terlibat dalam pemberian nilai akademik adalah guru mata pelajaran sedangkan nilai non akademik adalah pelatih masing-masing.

Kelima adalah hambatan pembelajaran kelas olahraga yaitu jam pembelajaran akademik peserta didik kelas olahraga yang dikurangi baik untuk jam latihan maupun jam dispensasi, ada tenaga pendidik yang kurang menyadari karakter peserta didik kelas olahraga, guru tersebut ketika mengajar di kelas olahraga memperlakukan sama dengan kelas reguler dan masalah biaya dikarenakan pada SMA Negeri 2 Batu ini sudah tidak ada uang SPP maupun uang bantuan yang lainnya sehingga menimbulkan kendala dalam pelaksanaan kelas olahraga yang harus mempunyai biaya besar. Solusinya adalah memodifikasi kurikulum pembelajaran dengan pengurangan 10 jam pelajaran diganti dengan pembelajaran menggunakan modul sehingga peserta didik kelas olahraga tidak tertinggal pelajaran dari kelas reguler, pengadaan semacam remidi, memberikan semacam pemahaman bahwa karakter peserta didik itu berbeda-beda begitu pula karakter peserta didik kelas olahraga kepada masing0masing guru, dan Bantuan dana dari dinas pendidikan maupun sarana prasana dari PENGCAB atau Pengurus Cabang dan pembebasan biaya sewa oleh Wali Kota Batu.

\section{Saran}

Berdasarkan penelitian yang dilakukan di SMANegeri 2 Batu, maka saran yang disampaikan terkait manajemen pembelajaran kelas olahraga di SMA Negeri 2 Batu. Bagi Kepala SMA Negeri 2 Kota Batu diharapkan secara terus menerus melakukan perbaikan dalam penyelenggaraan program kelas olahraga dan tetap konsisten dalam pengadaan kelas olahraga, jika bisa kelas olahraga lebih dioptimalkan misalnya dengan dukungan sarana maupun prasarana.

Kedua bagi Guru SMA Negeri 2 Kota Batu diharapkan guru dapat memahami perbedaan karakter antara peserta didik kelas olahraga dengan kelas reguler yaitu dengan cara melakukan pendekatan personal kepada peserta didik kelas olahraga untuk mengenali karakter peserta didik sehingga proses pembelajaran akademik maupun pembelajaran non akademik dapat berjalan dengan baik.

Ketiga bagi Ketua Jurusan Administrasi Pendidikandiharapkan agar jurusan dapat lebih luas lagi dalam mengkaji tentang manajemen pembelajaran sebagai pendalaman dalam ilmu manajemen pendidikan khususnya mata kuliah manajemen kurikulum dan pembelajaran untuk ke depannya.

Keempat bagi peneliti lain diharapkan kepada peneliti yang akan datang untuk menyempurnakan teori hasil penelitian yang 
telah ditemukan dan dapat menyempurnakan kekurangan penelitian ini pada fokus perencanaan pembelajaran kelas olahraga yang terjadi pada awal pembelajaran dimana peneliti masing belum dapat terlibat secara langsung maka diharapkan peneliti lain bisa mendapatkan metode observasi dan dokumentasi secara langsung sehingga diharapkan dapat menyempurnakan penelitian pembelajaran kelas olahraga.

\section{DAFTAR RUJUKAN}

Majid, A. 2007. Perencanaan Pembelajaran Mengembangkan Standar Kompetensi Guru. Bandung: PT Remaja Rosdakarya.

Majid, A. 2013. Strategi Pembelajaran. Bandung: PT Remaja Rosdakarya.
Moleong, L, J. 2012. Metodologi Penelitian Kualittaif Edisi Revisi. Bandung: PT Remaja Rosdakarya.

Mu'arifin. 2009. Dasar-dasar Pendidikan Jasmani Dan Olahraga. Malang: Universitas Negeri Malang.

Paturusi, A. 2012. Manajemen Pendidikan Jasmani Dan Olahraga. Jakarta: Rineka Cipta.

Rohman, M danAmri, S. 2013. Strategi dan Desain Pengembangan Sistem Pembelajaran. Jakarta: Prestasi Pustakaraya.

Sagala, S. 2006. Konsep dan Makna Pembelajaran Untuk Membantu Memecahkan Problematika Belajar dan Mengajar. Bandung: Alfabeta.

Ulfatin, N. 2014. Metode Penelitian Kualitatif di Bidang Pendidikan: Teori dan Aplikasinya. Batu: Bayumedia Publishing. 